\title{
The Impact of Information and Communication Technology (ICT) on ASEAN Trade Flow
}

\author{
Iwan Hermawan \\ Research Center \\ Expertise Body of Indonesian House of \\ Representative \\ Jakarta, Indonesia \\ nawih09@gmail.com
}

\author{
Eka Budiyanti \\ Research Center \\ Expertise Body of Indonesian House of \\ Representative \\ Jakarta, Indonesia \\ eka.budiyanti@gmail.com
}

\author{
Edmira Rivani \\ Research Center \\ Expertise Body of Indonesian House of \\ Representative \\ Jakarta, Indonesia \\ 3dm1r4.er@gmail.com
}

\begin{abstract}
Information and communications technology (ICT) would drive the acceleration of digitalization era, including dynamics of trade flow among ASEAN countries, both in low or high-tech also. Basically each country has different resources, and so why many factors must be known to be a winner. This aim of study was to analyze the impact of ICT existence on ASEAN trade flows. Panel data for 10 ASEAN countries for a period from 2012 to 2016 was employed to construct Gravity Model. To estimate that model, we applied Poisson Pseudo Maximum Likelihood (PPML). All data came from World Bank, WITS, CEPII, IMF, and ITU. The result showed that ICT has significantly positive impacts on both trade flow ASEAN market. If we elaborated in detail, according to (a) the sector, ICT in trade of hi-tech commodities was more attractive effort than low-tech commodities and (b) the existence, the adult literacy rate as ICT skills was more dominant factor influenced in trade flow among ASEAN countries compare ICT access and usage. Some policy recommendations were how to develop workers' skills, mitigation issue on digital economy, and develop domestic ICT industry.
\end{abstract}

\section{Keywords-ICT, ASEAN, trade, gravity model}

\section{INTRODUCTION}

The world is changing revolutionary because of the internet, including in international trade. According to the World Economic Forum Report (2015) indicated a 10 percent increase in internet access correlates with an increase of 1.2 percent in economic growth in developing countries. Access to internet has changed the way we do our traditional business or daily activities [1]. Using the internet and ecommerce platforms, companies of all sizes are much more visible to prospective customers around the world. Research shows that they are much more poised to export and import and scale their sales than ever before [2].

ASEAN is now transitioning towards a digital economy [3]. ASEAN digital economy is expanding at an unprecedented pace. It is projected to grow significantly, adding an estimated USD200 billion by year 2025 [4]. And particularly for Indonesia's digital economy alone is poised to become the largest in ASEAN with market value triples to USD100 billion by 2025 from USD27 billion in 2018. It's promising more jobs and consumer choices for emerging tech-savvy generation [5]. On the other side, combined gross domestic products (GDP) of almost USD2.8 trillion in 2017 and projected to touch USD4 trillion by 2022, when it is forecast to become the fifth-largest economy worldwide
[6,7]. Therefore, ASEAN becomes more prospective digital economy market and basically, all of them need information and communications technology (ICT) goods as a tool or supporting of the digitalization. So ICT, and in particular the internet, has become a core part of the economy and embedded infrastructure, progressively underlying all aspects of socio-economic growth and development in ASEAN region.

But many significant roadblocks stand in the way of realizing that potential. ASEAN still faces significant barriers to growing the digital economy, particularly in ICT. Based on International Telecommunication Union (ITU) data year 2017, internet user (person) are so vary each country, starting from 25,5 percent (Lao) until 94,9 percent (Brunei Darussalam, Singapore). As we know, internet access is a core of the rolling digital era and give a domino effect for the development of ICT industry. The width digital access gap, make digital economy cannot run smoothly and impact on regional interconnectivity.

On the other hand, without adequate ICT infrastructure, such as electricity production and internet bandwidth, internet access also cannot occur. And according to Global Information Technology Report, most of ASEAN country has ranking above 70 out of 139 countries, except Singapore. This means that the role of ICT trade within ASEAN region would be crucial to ensure that every ASEAN country is fulfilled its ICT needs.

Based on that background, this aim of study was to analyze the impact of ICT on ASEAN trade flows. Other studies have been conducted, but still rare scrutinize on impact of ICT on trade flow (especially ICT and non-ICT) and ASEAN corridor empirically. Research with the same nuance but still different, for example, World Bank [4]; PWC [7]; Wardani, Azizurrohman, and Tanthow [8]; and LAO ICT Commerce Association [9].

\section{METHOD}

\section{A. Data}

The secondary data was needed to build the Gravity Model. It was panel data with time series year 2012-2016 and cross section 7 countries, namely Indonesia, Malaysia, Thailand, Singapore, Philippines, Viet Nam, and Cambodia. And data periods were based on data availability, both exogenous and endogenous variable. Those data came from World Bank (World Development Indicators), Comtrade, World Integrated Trade Solution (WITS), Centre d'Études 
Prospectives et d'Informations Internationales (CEPII), International Monetary Fund (IMF), and so on. Data processing employed Stata 13 software.

For endogenous variables, we used trade flows for ICT and agroindustry goods, previous as hi-tech commodities and later as low tech commodities representative. This division was to compare the difference among commodities when touches by internet or technology. In this research, we used HS-2 digit (2012), namely 11-24, 40, 44, 50-52 as agroindustry sector (in value export) and the other hand, HS6 digit (2012), namely ICT01 includes computers and peripheral equipment $(844331,844332,847050,847130$, $847141,847149,847150,847160,847170,847180,847190$, $847290,847330,847350,852841,852851,852861)$; ICT02 includes communication equipment (851711, 851712, $851718,851761,851762,851769,851770,852550,852560$, 853110); ICT03 include consumer electronic equipment (851810, 851821, 851822, 851829, 851830, 851840, 851850, $851890,851920,851930,851950,851981,851989,852110$, $852190,852210,852290,852580,852712,852713,852719$, $852721,852729,852791,852792,852799,852849,852859$, $852869,852871,852872,852873,950450)$; ICT04 includes electronic components (852321, 852352, 853400, 854011, 854012 , 854020, 854040, 854060, 854071, 854079, 854081, $854089,854091,854099,854110,854121,854129,854130$, $854140,854150,854160,854190,854231,854232,854233$, 854239, 854290); and ICT05 includes miscellaneous (852351, 852359, 852380, 852910, 852990, 901320). All those ICT was classified by United Nations Conference on Trade and Development (UNCTAD) (in value export). The limitation of this study did not measure "other value", include like talent, capital, ideas, and culture.

\section{B. The Approach Analysis}

We use the Gravity Model that has been widely used by other researchers. A modified Gravity Model was used to evaluate the factors of trade flows of commodities in ASEAN region. This model was able to capture the factors that influence on trade flow. The form detail can be seen from Anderson [10] and some case of Gravity Model application in Indonesia done by, such as Wahyudi \& Anggita [11]; Effendi [12]; Inayah, Oktaviani, \& Daryanto [13]; and Ekanayake, Mukherjee, \& Veeramacheneni [14].

The final form of gravity specification was presented in equation (1), where the sub-index $i$ and $j$ refer to the origin and partner country, respectively, whilst $t$ refers to the year. Related with ICT indicators, we used fixed broadband subscriptions per 100 inhabitants as represented dimension of ICT use, international internet bandwidth as represented dimension of ICT access, and adult literacy rate as represented dimension of ICT skills.

\footnotetext{
$\mathrm{X}_{\mathrm{ijt}} \quad=\alpha+\beta_{1} \operatorname{lgdp}_{\mathrm{it}}+\beta_{2}$ ddist $_{\mathrm{it}}+\beta_{3}$ linder $_{\mathrm{it}}+$ $\beta_{4} \mathrm{fbr}_{\mathrm{it}}+\beta_{5}$ liibr $_{\text {it }}++\beta_{6}$ lalrs $_{\text {it }}+\varepsilon$

$\mathrm{X}_{\mathrm{ijt}} \quad$ : export of country $j$ from country $\mathrm{i}$ (mio USD), the data came from WITS.

$\operatorname{lgdpp}_{\text {it }}: \log$ GDP of destination country (mio USD).

ddist $_{\text {it }}$ : distance between the capital cities of the importing and exporting country $(\mathrm{km})$, the data came from CEPII.

linder $_{\mathrm{it}} \quad$ : Linder effect country $i$ (percent).
}

fbr $2_{\text {it }}$ : ratio fixed broadband subscriptions per 100 inhabitants over internet usage country $i$, the data came from ITU.

lniibr : $\log$ international internet bandwidth country $i$ (ranking), the data came from ITU.

lalrs it $_{\text {ing }} \log$ adult literacy rate country $i$ (score), the data came from ITU.

$\alpha \quad$ : intercept.

$\beta_{1}-\beta_{6} \quad:$ parameter estimation

$\varepsilon \quad$ : error term.

Zero-observations and heteroscedasticity problem often occurs in trade data. There are three methods how to solve it, namely selection bias, using very small number, and Pseudo Poisson Maximum Likelihood (PPML). Silva and Tenreyro [15] revealed it was a robust approach and used in number of Gravity Model, such as Westerlund \& Wilhelmsson [16] and Akhvlediani \& Śledziewska [17]. PPML type employed here was PPML fixed effect and to ensure PPML was robust, this research conducted the Ramsey Regression Equation Specification Error Tests (RESET).

\section{RESULT AND DISCUSSION}

Based on data processing, the results can be seen in Table I, which showed the impact of ICT on ASEAN's agroindustry commodity exports. In general, the variables that have a significant effect which were ratio GDP of origin over partner country, distance, fixed broadband, and adult literacy rate. All the sign of parameter estimation was accordance with the theory.

When there was increase in ratio of GDP origin over partner country GDP by 1 percent, it would increase origin country exports by USD4.38 million, ceteris paribus. GDP's partner country and also origin were an essential consideration for exporters decide to do trade or not. GDP as indicator of purchasing power would affect the number and type of goods traded with. This result was in line with another researcher, such as Sari \& Widyastutik [18]; Rahmah [19]; and Wardani, Azizurrohman, \& Tanthow [8].

TABLE I. ESTIMATION RESULT OF GRAVITY MODEL ON LOW-TECH COMMODITIES

\begin{tabular}{|l|l|c|c|c|}
\hline Variables & \multicolumn{1}{|c|}{ Definition } & Coef. & $\mathbf{z}$ & $\mathbf{P}>\mathbf{z}$ \\
\hline rgdp & $\begin{array}{l}\text { Ratio GDP of origin } \\
\text { over partner country }\end{array}$ & $4.376^{* * * *}$ & 3.100 & 0.002 \\
\hline ddist & Distant & $-0.005^{* * * *}$ & -3.610 & 0.000 \\
\hline fbr2 & $\begin{array}{l}\text { Ratio fixed } \\
\text { broadband over } \\
\text { internet usage }\end{array}$ & $0.009 * * * *$ & 2.930 & 0.003 \\
\hline liibr & $\begin{array}{l}\text { International } \\
\text { internet bandwidth }\end{array}$ & -0.024 & -0.080 & 0.933 \\
\hline lalrs & Adult literacy rate & $9.475^{* * *}$ & 2.550 & 0.011 \\
\hline _cons & Constant & $-34.960 * *$ & -1.950 & 0.051 \\
\hline
\end{tabular}

Pseudo log-likelihood: -12383.29

$\mathrm{R}^{2}=0.82$

RESET: $\operatorname{chi} 2(1)=6.22 * * *$

Endogenous variable: export between country (in level) 
Fixed broadband variables and adult literacy rate were the variables that reflect the ICT. Based on run data showed that fixed broadband tends to have positive impact on increasing in low-tech commodities exports within ASEAN countries. Fixed broadband network fulfilled internet needs, data on housing, buildings, and offices, also needed by cellular networks. However, the quality of cable or fiber optic network is still better and more stable than satellite or even radio. When fixed broadband increased by 1 percent, then it would increase low-tech commodities exports (agroindustry) by USD0.01 million, ceteris paribus.

Based on, low-tech commodities, such as agriculture, the major challenges farmers face is lack of marketplace information. Most of farmers depend on word-of-mouth information. Farmers also suffer from poor market infrastructure and unfair trading systems forcing them to accept low prices, all of which inhibit them from obtaining a better income. Using internet with good fixed broadband network would make them can easily fill in this information gap. These systems allow farmers to understand current market conditions and make sound decisions to produce higher yield crops and increase their income [20].

On the other hand, adult literacy rate was significant variable also, even very responsive. If adult literacy rate increased by 1 percent, it would increase origin country ICT's exports by USD9.48 million, ceteris paribus. According OECD [21], globalization, technological change, and organizational development are shaping both the supply and demand for higher levels of literacy skills in the information age (digital era). Skills are becoming increasingly important in the knowledge economy, both for individuals and macro level. Countries with higher levels of skills will adjust more effectively to challenges and opportunities opened up by globalization because their firms will be more flexible and better able to absorb and adapt new technologies and to work with new equipment.

Whereas on distance variable as proxy of transportation costs, the farther away of trade distance then it would reduce exports value between countries. If there is increasing in distance of $1 \mathrm{~km}$, it would have sent down the export by USD0.01 million, assuming ceteris paribus. The farther of the distance then larger in transportation cost. This result was same as with Fontagné, Mitaritonna, and Signoret [22]. As noted, the presence of ICT in the end of trade can make cheaper transportation costs. For this reason, further research needs to be done by elaborating simultaneously if the distance variable is adjusted or modified due to the presence of ICT in trade.

Today, the phenomenon of global value chains (GVCs) is a product of the lowering of transport costs and the information technology revolution whose advances have given firms the ability to coordinate their production needs on a real-time basis, no matter what the geographical location of the producer. The impacts of GVCs may differ as well, depending upon product line and relative location on the value chain. Value chains that operate in mass consumption products (often electronics) may have very different development consequences from value chains that involve agricultural products or those that are technology intensive [23]. For example, Assembly Company of smart phone Iphone, Pegatron, has moved to Indonesia [24].
Next, what about the impact of ICTs on hi-tech commodities (ICT) directly. Based on Table II, all variables influenced ASEAN ICT's export, such as GDP of partner country, Linder effect, fixed broadband, international internet bandwidth, and adult literacy rate. In general, it seems that the impacts of ICT on ICT trade are more attractive than on agro-industry. Industrial commodities are relatively more easily traded or transferred from one country to another compared to agricultural products that are bulky and not durable. Therefore, the issue of increasing the scale of the agricultural sector towards industrialization needs to be addressed here.

If GDP in partner country increased by 1 percent, it would increase origin country ICT's exports by USD7.35 million, ceteris paribus. However, the partner country's income become an important consideration for ICT's exporter, include another factors. And ICT is one of industrial commodity and off course possible to emerge a Linder effect and here it was proven. The smaller gap between the income of the country of origin and the partner country, the exports will be even greater. When gap between the income of the country of origin and the partner country (within ASEAN region) decreased by 1 percent, then export ICT would increase by USD15.18 million, ceteris paribus.

The other important thing, there were 3 indicators on ICT also significantly influenced ICT trade, such as (1) fixed broadband, (2) international internet bandwidth, and (3) adult literacy rate. This indicated that ICT's tools or devices or facilities were able to encourage the acceleration of ICT trade. If ratio fixed broadband subscriptions per 100 inhabitants over internet usage increased by 1 percent, it would increase ICT exports by USD0.08 million, ceteris paribus. When international internet bandwidth increased by 1 percent, it would increase ICT exports by USD1.45 million, ceteris paribus.

TABLE II. ESTIMATION RESULT OF GRAVITY MODEL ON HI-TECH COMMODITIES

\begin{tabular}{|c|c|c|c|c|}
\hline Variables & Definition & Coef. & $\mathbf{z}$ & $\mathbf{P}>\mathbf{z}$ \\
\hline lgdpp & $\begin{array}{l}\text { GDP of partner } \\
\text { country }\end{array}$ & $7.352 * * *$ & 2.220 & 0.026 \\
\hline ddist & Distant & -0.006 & -0.670 & 0.501 \\
\hline linder & Linder effect & $-8.447 * * * *$ & -3.620 & 0.000 \\
\hline fbr2 & $\begin{array}{l}\text { Ratio fixed } \\
\text { broadband over } \\
\text { internet usage }\end{array}$ & $0.078 * * *$ & 2.430 & 0.015 \\
\hline liibr & $\begin{array}{l}\text { International } \\
\text { internet } \\
\text { bandwidth }\end{array}$ & $-1.447 * * * *$ & -3.580 & 0.000 \\
\hline lalrs & Adult literacy rate & $72.772 * * * *$ & 3.850 & 0.000 \\
\hline _cons & Constant & $-340.220 * * * *$ & -3.570 & 0.000 \\
\hline \multicolumn{5}{|c|}{ Pseudo log-likelihood: -19757.969} \\
\hline \multicolumn{5}{|c|}{ RESET: $\operatorname{chi} 2(1)=7.58 * * * *$} \\
\hline Endogenor & variable: export bet & een country (in & & \\
\hline
\end{tabular}


Although the sign of international internet bandwidth variable was negative, it showed in ranking position (not score or value). That is, higher ranking was the worse of the position, then so why it would decrease ICT export. And when adult literacy rate increased by 1 percent, it would increase ICT exports by USD71.77 million, ceteris paribus. From here we can see that developing ICT in ASEAN region as a representation of rolling the digital era, it requires ICT goods also. Three of them were interconnected to encourage positively ICT trade flow in ASEAN region. Point in trade access, off course, must also be supported by the usage and the ability of those who use them.

For Indonesia, now the number of active internet users has exceeded 140 million users. As the largest population in Southeast Asia, Indonesia has the opportunity to become a Digital Powerhouse in the ASEAN region. To make it happen, the development of ICT must be a priority and the good news is that the connectivity network development has exceeded 90 percent. But homework left behind is how to use the connection effectively. The contribution of Indonesia's economy digital has only reached 4 percent of GDP. However, the prospect of growth is quite bright in the future. The projection of E-Commerce transaction value which reached USD130 billion in 2020. This is what makes Indonesia is called "Digital Energy Asia" [25].

\section{CONCLUSION AND POLICY IMPLICATION}

The development of ICT makes trade between ASEAN countries escalated. It drove an increase of exports by USD0.1-72.78 million. This is an important finding, each ASEAN country can use it to support national and regional economic growth, include boosting for a Single Market ASEAN in the digitalization era.

Generally, a main factor that affect on ASEAN's ICT trade included GDP, distant (transportation cost), and ICT facilities (access, usage, and skills). Three of them in trade involving high technology (ICT) or low technology (primary commodities) are equally influenced by the existence of ICT trade, but industrial goods with high technology touch looks more attractive than agricultural goods.

The government needs to focus on the development of ICT as industrial commodities and also ICT as facilities are well fulfilled. It would help us to take the advantage of digital trade era booming. Some notes that it should be paid attention by the government are (1) encourage adult literacy activities, through training (informal education) and vocational education, to improve workers' skills. The higher levels of skills will adjust more effectively to challenges and opportunities in trade flow, (2) ensuring ICT is available to its citizens, must also be equipped with various rules to maintain data security or mitigation steps, and (3) some of ASEAN country, including Indonesia, have not yet development of domestic ICT industry full or assembly production. It efforts would require a large investment and cross-sectoral support how to create investment-conducive situation. It can reduce dependency and at the same time encourage employment.

\section{REFERENCES}

[1] Z. Xing, "The impacts of Information and Communication Technology (ICT) and e-commerce on bilateral trade flows," Rapid-
Response Note, Promoting Agriculture, Climate and Trade Linkages in The East African Community-Phase 2, 2016.

[2] K. Suominen, Fuelling trade in the digital era: Policy roadmap for developing countries. Geneva: International Centre for Trade and Sustainable Development (ICTSD), 2017.

[3] ASEANSec, The ASEAN ICT, Masterplan 2020. Hanoi: TRPC Pte Ltd, 2015.

[4] World Bank, The digital economy in Southeast Asia strengthening the foundations for future growth. Washington, DC: World Bank, 2019.

[5] The Jakarta Post. "Indonesia's digital economy to dominate Southeast Asia by 2025". thejakartapost.com. https://www.thejakartapost.com/news/2018/11/28/indonesias-digitaleconomy-to-dominate-southeast-asia-by-2025.html (accessed August 21, 2019)

[6] ASEANsec, ASEAN key figures 2018. Jakarta: ASEAN Secretariat, 2018.

[7] PCW, The future of ASEAN time to act. Singapore: PwC Growth Markets Centre, 2018

[8] D.T.K. Wardani, M. Azizurrohman, \& A. H. Tanthow, "The effect of Information and Communication Technology (ICT) on Indonesian bilateral trade: Evidence from ASEAN countries". $2^{\text {nd }}$ International Conference and Call for Paper on Trade, $5^{\text {th }} 6^{\text {th }}$ September 2018, Trade Analysis and Development Agency, Ministry of Trade Republic of Indonesia, Jakarta.

[9] Lao ICT Commerce Association (LICA), Research for ASEAN Free Trade Agreement impact to Lao ICT industry. Prepared for The Project on Human Resource Development in the IT Service Industry at NUOL Project, JICA. Vientiane Capital: Japan International Cooperation Agency, 2013.

[10] J.E. Anderson, "A theoretical foundation for the Gravity Equation," The American Economic Review, Vol. 69, No. 1, pp. 106-116, 1979.

[11] S. T. Wahyudi \& R. S. Anggita, "The Gravity Model of Indonesian bilateral trade," International Journal of Social and Local Economic Governance, Vol. 1, No. 2, pp. 153-156, 2015.

[12] Y. Effendi, "ASEAN free trade agreement implementation for Indonesian trading performance: A Gravity Model approach," Buletin Ilmiah Litbang Perdagangan, Vol. 8, No. 1, pp. 73-92, 2014.

[13] I. Inayah, R. Oktaviani, \& H. K. Daryanto, "The analysis of export determinant of Indonesian pepper in the international market," International Journal of Science and Research, Vol. 5, Issue 11, pp. 1856-1860, 2016

[14] E. M. Ekanayake, A. Mukherjee, \& B. Veeramacheneni, "Trade blocks and the Gravity Model: A study of economic integration among Asian Developing Countries," Journal of Economic Integration, Vol. 25, No. 4, pp. 627-643, 2010

[15] J. M. C. S. Silva and S. Tenreyro, "The log of gravity," The Review of Economics and Statistics, 88(4), pp. 641-658, 2006.

[16] [16] J. Westerlund and F. Wilhelmsson, "Estimating the Gravity Model without gravity using panel data," Applied Economics, 43, pp. 641-649, 2011.

[17] T. Akhvlediani and K. Śledziewska, "Implications of the european integration: revisiting the hypothesis of 'hub-and-spokes' model," Baltic Journal of Economics, 17(1), pp. 45-56, 2017.

[18] K. R. Sari dan Widyastutik, "Faktor yang mempengaruhi dan estimasi tarif ekuivalen NTBs ekspor kayu lapis Indonesia," Buletin Ilmiah Litbang Perdagangan, 9(1), pp. 95-108, 2015.

[19] K. N. Rahmah, "Trade flows analysis and the role of standards on Canned Tuna trade," M.S. thesis, Institut Pertanian Bogor, Bogor, Indonesia, 2016

[20] BCSD Singapore, PBE, Indonesia BCSD, \& Viet Nam BCSD. "Efficient agriculture, stronger economies in ASEAN, Private sector perspectives for policy makers." White Paper. BCSD Singapore, PBE, Indonesia BCSD and Viet Nam BCSD, 2016.

[21] OECD, Literacy in the information age, Final report of the international adult literacy survey. Paris: Organisation for Economic Co-Operation and Development, 2000

[22] L. Fontagné, C. Mitaritonna, and J. Signoret, "Estimated tariff equivalents of services NTMs," CEPII Working Paper, 2016

[23] S. Stephenson, Global value chains: The new reality of international trade. In "Global Value Chains: Development Challenges and Policy Options, Proposals and Analysis." Geneva: International Centre for 
Trade and Sustainable Development and World Economic Forum, 2013, pp. 3-14.

[24] Agung Hidayat. "Kuartal I-2019, perusahaan perakit Iphone asa China bakal pindahkan pabrik ke Batam." kontan.co.id. https://industri.kontan.co.id/news/kuartal-i-2019-perusahaan-perakitiphone-asal-china-bakal-pindahkan-pabrik-ke-batam (accessed August 20, 2019)
[25] D. Ikhsanti. "Pasar digital sumbang 4 persen PDB Indonesia." aturduit.com. https://www.aturduit.com/articles/pasar-digitalsumbang-4-persen-pdb-indonesia-2017/ (accessed August 20, 2019). 